\title{
Electoral Offenses in The Common Law System
}

\author{
Vladimir Mulaj, MSc, PhD Candidate \\ International University of Tirana, Albania
}

\begin{abstract}
Electoral behavior is a new element in the political analysis of democracy in Albania. Distinctive features of the Albanian transition distinguish other models of the former communist countries, as well as significantly differ with Western models and electoral behavior analysis of the relations between political actors and citizens voting. Penal Code of the Republic of Albania remains the basis of criminal law to sanction criminal acts in the election. The object of criminal misconduct are directly related to the normal criminal and legal protection and free elections as well as the Albanian Constitution provides all these obstacles to electoral subjects committed by force or by any other means which directly affect the normal performance electoral system. Barriers can be done with physical or psychological, and consists in blocking commissioners election materials, election materials decay affecting decay electoral system unfairly supported a particular political party or a coalition of political parties that present list candidacy according to the rules defined in the electoral code. Albanian Constitution as the fundamental law of the Albanian state provides for the rightness of the equality of the vote for all Albanian citizens The vote is the democratic way that every citizen expressing the opinion and its political will but to have democratic value ratings should be personal equal, free and secret. The right to vote is a political right provided by the Albanian Constitution and the Universal Declaration of Human Rights and as such is closely linked to democracy, the sovereignty of the people and citizens. Total vote, or the right to get to the polls all Albanian citizens, men and women, and in fact is the greatest achievement of the twentieth century. According to the Electoral Code of the Republic of Albania every citizen exercises his right to vote at his polling station, where placed under citizen's location criteria. Voting centers organized in such a way as to facilitate the voting process and ensure the secrecy of the vote. Democracy lives by opinions competition. In all areas of society, in the family and at school, association and enterprise, democracy needs a social climate which stimulate open discussion on the differences of opinion.
\end{abstract}

Keywords: electoral; offenses; common law; system; Albania 


\section{Introduction}

In this article I want to introduce a study on criminal Albanian electoral system. Electoral behavior $^{1}$ is a new element in the political analysis of democracy in Albania.Due to the lack of tradition and problems in the creation of two decades of transition elections have proved insufficient to form an assessment system on the electoral behavior of the electorate. Distinctive features of the Albanian transition distinguish other models of the former communist countries, as well as significantly differ with Western models and electoral behavior analysis of the relations between political actors and citizens voting.

Given the problems of development performance choices ranging from the lack of transparency of the vote, rock the vote, the secrecy of the vote, has given way to prevent Albanian lawmakers and condemn these actions illegal and depressing for democratization and integration of Albania to the EU.

\section{Legal Framework}

Penal Code of the Republic of Albania remains the basis of criminal law to sanction criminal acts in the election, which has paid special attention to these works, which are defined in Articles 325, 326, 326-a, 327, 327-a, 328, 328-a, 329, 330, 330-a 331 and 332 PCA (Penal Code of Albania) entered into force on law nr.23.2012. These articles stipulate criminal action against all persons who in any way impede the voters to exercise their right to vote, take corrupt activities, use violence on election day, voting several times, discover the secret ballot, cheat at the polls and destroy various forms of ballot papers. The penalties provided in these provisions provide for fines, bail and effective imprisonment of up to five (5) years. Based on the format of election crimes that were committed in Albania, it turns out that it has no frame to define deficiency all criminal actions about the electoral process, so the legislator in the Criminal Code offense of categorized as separate figures offenses.

\section{Section $325^{2}$ - Obstruction of subjects for elections to representative bodies.}

According to article 325 of the Criminal Code Albanians the law defines the offense of obstructing the normal course of voting during the elections. Article in question came into force to strengthen the element of freedom of the vote of any particular political entity, which has earned it the percentage required by the electoral code, where there

\footnotetext{
${ }^{1}$ Current Electoral System in Albania - Since the 2009 parliamentary elections have to do with the new electoral systems (proportional), with the new political situation (creating large coalitions against ideological parties and the absence of a dominant party in government), as well as establishing the first independent profiles from a set of constitutional institutions, with an active role in decisionor political oversight have created the opportunity for a sound analysis and illustrate the process of the relations between political actors and voters.
}

${ }^{2}$ Albanian Criminal Code - "Prevention of violence or any other electoral entities regularly to develop their activities in accordance with the law during the election campaign, is punishable by a fine or imprisonment up to three years." 
are no more disputes and where the expression of political will of the sovereign is represented totally, where we as citizens worthily address as the constitution provides.

The object of the offense - is clearly shown in this article how important electoral system as a guarantee of stability and democracy. The object of criminal misconduct are directly related to the normal criminal and legal protection and free elections as well as the Albanian Constitution provides all these obstacles to electoral subjects committed by force or by any other means which directly affect the normal performance electoral system.

Objective side - under Article 325 it seems clear that the offense under this section clearly states that the offense of violation committed with violence or any other means or otherwise illegal. It seems very clear that the offense in question head with action but also does not exclude other cases which can be performed even by omission. Article 325 states: "... in every other way", which means that you should be left open to interpretation jurisprudence space under concrete cases. Barriers can be done with physical or psychological, and consists in blocking commissioners election materials, election materials decay affecting decay electoral system unfairly supported a particular political party or a coalition of political parties that present list candidacy according to the rules defined in the electoral code.

Subject - This is a particular situation and moment that is precisely the holding of elections and for certain subjects where Article 325 itself PC (Penal Code of Albania) categorizes term electoral subjects. Electoral subjects, means natural persons who represent certain political party or certain party coalitions during the course of the election.

Subjective side - Absolutely the law provides for punishment of the subject when the offense was committed with direct intent. Which means, punish all electoral subjects who willingly and willfully seek to prevent electoral subjects for the normal progress of the electoral system in order to favor or harm one or another political party, or the respective candidates.

Punishment prescribed for this criminal offense is a fine or imprisonment up to 3 years. $^{3}$

\footnotetext{
${ }^{3}$ As in the case of the 2009 elections in the municipality Shale Lezha Hall where 5 people were arrested because they did block the road commissioners to go to the polling station. For this reason they were charged under Article 325 Albanian Penal Code.
} 


\section{Article 326 PCA $^{4}$ - "Falsifying documents and election results"}

The holding of elections in Albania in the majority has shown once again for the lack of Albanian princes to consolidate democratic mechanisms to estimate electoral system as our constitution provides as the foundation of a democratic society.

For a long time the OSCE / ODIHR ${ }^{5}$ stated that the Electoral Code is a complete technical foundation for the development of democratic elections and that what is needed most is the commitment of political parties to respect the letter and to intent the law. The elements of these crimes do to exclude the possibility that these acts have been isolated in certain locations.

Misuse of official position, politicized administration and other options related benefit political parties to consider power as a key tool to provide material and non-material benefits to members and their supporters. Therefore, there is a strong motivation to win elections at any cost, sparing no means. Before the 2010 general elections, the judiciary had a poor or almost nonexistent response to crimes related to election fraud. Prosecutors and judges ignoring the fact that a number of other crimes in the country arising from the election crimes, over the years, and have implemented a wrong policy (non) action.

Consequently, they only have stimulated stealing votes. Today penal code Article 326 provides that: falsification of documents and election results constitute a criminal offense.

The object of the offense- Object of the offense of forgery of documents and election results is the legal protection of the right of the Albanian people, to have free and fair elections as the constitution stipulates exactly how the guarantee of democracy and development a country, when they are damaged or affected by the use of false documents, accurate replacement of perjury, forgery and election outcomes assessments by different entities.

Objective side - clearly understood, that the offense in this case is carried out direct action subject which changes the data, drafting documents or with false truths replacement precisely in order decay and change election results. Penalty to Penal Code provides in Article 326 is punishable by a fine or imprisonment up to 5 years.

Subject - can be any person who is charged with election set for normal development (may be the function of members of the CEC monitors, etc.) performs the action of

\footnotetext{
${ }^{4}$ Election documents presentation of data, circumstances, figures who are known to be inaccurate, the preparation of false documents or false accurate replacement, made by persons in charge of the development, evaluation, tabulation or document storage shall be punished by a fine or imprisonment up to five years.

${ }^{5}$ See earlier reports by the OSCE / ODIHR and the revision of the Electoral Code in address: http://www.osce.org/odihr/ elections/Albania
} 
falsifying election documents. It is clear that, if the unlawful act committed by persons who have a specific task and use this position for falsifying election documents criminal responsibility for these subjects is even higher because done in abuse of office.

Subjective side- Section 326 PCA is written very clear and leaves no room for interpretation, means that any person who commits the offense of forging documents and purposefully direct election results, to harm or prejudice to the democratic development of the electoral system. If this offense when committed by persons who have a duty to administer the electoral process, or has caused serious consequences in the conduct of the vote, has violated the integrity of the election result or bring their invalidity, shall be punished with imprisonment of three to seven years and a fine from three hundred thousand to six thousand.

Article 326-a PCA added by Law no. 23/2012 provides for willful damage of election material.

Practically, means punishment of all persons who willfully disrupt the damage or replace the law, shall be punished by imprisonment from 3 to 6 years.

If these illegal activities done by people who are on election duty manager or in partnership, or more than once, or have serious consequences for the conduct of elections affecting election results constitutes an aggravating circumstance and provided a penalty from three to eight years and a fine of two hundred to seven hundred.

\section{Article 327 - Violation of the secrecy of the vote}

Albanian Constitution as the fundamental law of the Albanian state provides for the rightness of the equality of the vote for all Albanian citizens The vote is the democratic way that every citizen expressing the opinion and its political will but to have democratic value ratings should be personal equal, free and secret. Voting is free and equal: ${ }^{6}$ the legal system should provide every citizen voters the opportunity to express complete freedom without incurring any form of pressure or threat which may make the decision of his vote.

Also, the vote should be secretcy which means that the mode of expression of the vote is to avoid any form of control over the vote.

\footnotetext{
${ }^{6}$ Section N.3 Electoral Code of the Republic of Albania - President of the Republic, deputies, councilors and the mayor are elected in general elections, direct and free elections by secret ballot. (2) No one dares to call the voter in voting process because voting responsibility, not requires the showing of the vote.
} 
The question is what happens if the secrecy of the vote is not respected?! What are the criminal responsibility in this case?

Answers found precisely in section 327 of the Penal Code which punishes precisely the violation of the secrecy of the vote.

The object of the offense: the protection of legal relations established in the Constitution and in the law no. 9087, dated 19.06.2003 "The Electoral Code of the Republic of Albania" to ensure that citizens perform free secret ballot. An injury or damage to these fundamental rights is punishable by penal code exactly from Article 327 , if committed by an offender with the purpose of direct action or inaction to prevent voting democratic performance and the principle of the secrecy of the vote.

The situation is even more serious when elective subjects which are required to monitor and ensure free elections: CEC members've observers commissioners, does not interfere with the removal of persons associated with the voting place because, according to the "Electoral Code" voting place must be located only without any accompanying voter, excluding even the closest people just to ensure secretion of the vote. Persons dissuade the principle of the secrecy of the vote thus affecting electoral entity criminally responsible for an offense, for "violating the secrecy of the vote" and is punishable by imprisonment from two months to two years. Offenses referred to in Article 327 PCA performed always by design regardless of intent and motive, which in this case does not affect the qualification of the offense.

Criteria is not to accompany the voters to the ballot but this makes an exception when an elderly person or disabled, illiterate, ill, requires free his desire to be accompanied by a relative to read the list and to assist in the conduct of elections, made on behalf of the one who has the right to vote.

Article 327 PCA amended by Law $23 / 2012$ respectively $327-a^{7}$ which punishes the voting process more than once and without being identified. Voting more than once in the same election, the vote for other people, presenting false identification documents or using other electoral documents constitutes a criminal offense and is punishable by up to three years.

If this action is allowed deliberately by the commissioner of CEC (Central Election Commission) is being punishable by one to five years. If the election commissioner willfully commits the voters identification, he has consumed the criminal misconduct and he is being punishable by three months to a year.

\footnotetext{
${ }^{7}$ Article 327 / a penal code changes to the law n. 23/2012 - "Voting more than once or not identified" Voting more than once in the same election, the vote for other people, presenting false identification documents or using other electoral documents is punishable by imprisonment of one to three years. Allowing knowingly performing this act of election commissioners shall be punished with imprisonment from one to five years. Allowing intentionally by the election commissioners voting without identification of the citizens under the law, constitutes criminal contravention and is punished with imprisonment from three months to one year.
} 


\section{Article $328^{8}$ PCA-Giving rewards and promises "commodity Score"}

The right to vote ${ }^{9}$ have a lot of people: men and women after age 18 years. Times have changed. Political ideological consensus is being disappeared, today we are the product of accounting choices and the economic and material interests which we have been often witnessed. Electoral Web has become a "commodity" to be used.

Those voters who voted provide more: jobs, tenders, favors before this situation can also go up to the award of a sack of flour for those families that provide a number of votes for a particular candidate. Also, do not forget the element of nepotism or guest favors recognition culture. Points, these political affairs are increasing every year. What I care about is only the vote. This is one element that is required with the tenacity to fight $\mathrm{EU}^{10}$ as exclusionary criteria and constraint integration of Albania. This is the exchange of votes as an increase in the number of voters is the most valuable commodity in the hand and the instrument best to dialogue between political power and the respective candidates support clans. This is the problem that includes dimensions are increasing between the legal and the illegal power. It is about the pre-election political affairs. The article in question has its object to protect the right of voting free and guarantee normal development of the elections in accordance with the law and constitution of the acts or omissions illegal. Article defines a variety of forms of electoral corruption namely: Offering or giving money or material goods, making promises of jobs where this refers to a career or a high position that the subject carries at the time of voting or where it is unemployed.

So, all of these methods are performed exactly to get the signature of the voter by screen required by the electoral law. The subject of this offense can be any person who promises, provision, or wants to juggle rewards to bribe voters with the purpose of directly or favored a particular candidate there by damaging the normal democratic electoral system.This constitutes a criminal offense under Section 328 and is being punishable by a fine.

While Article 328-a PCA amended by Law n.23/2012 for situations where persons are employed in administration, public institutions, in the absence of their will or by using administrative measures in order to illegal, for the sole purpose their participation in electoral activities, a certain electoral subject is the article in question a criminal offense and is punishable by fine or imprisonment up to six months.

\footnotetext{
${ }^{8}$ Section 328 Criminal Code amendments to the law n. 23/2012 "Giving rewards and promises" - Offering or giving money or material goods, making promises of jobs or other favors in any form, in order to get the firm to submit candidate for vote in a particular way or to take part or not to vote, constitutes criminal contravention and is punished with imprisonment from six months to two years. Receipt of money, goods, and other favors promises versus performing the above actions, constitutes criminal contravention and is punishable by a fine.

${ }^{9}$ Article 45 / of the Constitution Albania: 1.Each citizen who has reached eighteen years old, even on election day, has the right to elect and be elected. Article 16 L.10019 / 2008 “The Electoral Code of the Republic of Albania” Criteria for inclusion of Voters.
}

${ }^{10}$ European Union 
Article $328-a^{11}$ in the second paragraph categorizes separately, subjects figures who function state employees who perform a task in public education, or duty or function in non-public education, and students who are forced by certain entities to take participate in electoral activities of an electoral subject, convicted of a criminal offense with imprisonment from three to one year.

\section{Article $329^{12}$ - Threat or rape against participants in elections}

The right to vote is a political right provided by the Albanian Constitution and the Universal Declaration of Human Rights and as such is closely linked to democracy, the sovereignty of the people and citizens. Total vote, or the right to get to the polls all Albanian citizens, men and women, and in fact is the greatest achievement of the twentieth century.

All this means that democracy can not stand if every citizen is not free in his political choices. And in a fragile democracy if we can call this way the problems for the conduct of free and fair are always present. Namely, to eliminate this phenomenon to guarantee freedom to vote on law changes to the electoral code n.23/2012 section 329 PCA, punishes all those subjects who threaten or violate the participants in the elections. So, the object of Section 329 is to protect the legal relations of those basic human rights recognized and guaranteed by the Albanian Constitution and the electoral code for a free vote of a full democracy.

Criminal infringement in this case is carried out to the voters or to the voters is therefore determined only in this category.

Article 329 PHC in the first paragraph, provides threat made to voters to force him to vote in a certain way or to take part or not to vote, this is a criminal offense and is punishable by three months to two years.

If the threat and exercise of violence committed against the commissioner, the observers, the vote counters or any other officer in charge of elections in order to prevent the conduct of the elections and the performance of a criminal offense and is punishable by imprisonment from six months to three years.

\footnotetext{
${ }^{11}$ Article 328 / a PHC amended by Law n.23/2012 "The obligation to participate in political activities" - Obligation of subordinate administrative citizens against their will or under the threat of the use of administrative measures, to take part in election activities an electoral entity constitutes a criminal offense and is punishable by fine or imprisonment up to six months. Obligation or organization to participate in electoral activities of an electoral subject of pre-university students from state employees who perform a task in public education, or duty or function in non-public education, constitutes criminal contravention and is punished with imprisonment from three months to a year.

${ }^{12}$ Article 329 PHC amended by Law n.23/2012 "threat or rape against participants in elections" - Threat made to voters to vote in a certain way or to take part or not to vote, constitutes criminal contravention and is punished from three months to two years. Threat or use of violence to become a broker, monitors, counters and any other officer in charge of elections to prevent the performance of duty or because of his activity in election administration is punished with imprisonment from six months to three years. When this offense is committed in collaboration or more than once punished by imprisonment from one to five years.
} 
When this offense is committed in collaboration or more than once punished by imprisonment from one to five years.

\section{Section $330^{13}$ - Obstruction of voters}

If these illegal actions or non-actions performed more than once to more than one voter, or carried out by the election commissioners shall be punished with imprisonment from one to five years.

According to Article ${ }^{14}$ of the Albanian Constitution, "Limitations of the rights and freedoms stipulated in this constitution may be established only by law in the public interest or for the protection of the rights of others."

Democracy lives by opinions competition. In all areas of society, in the family and at school, association and enterprise, democracy needs a social climate which stimulate open discussion on the differences of opinion. Representation of personal opinion should be allowed and encouraged as persistent questions. Why and for what reason! No undisputed orders and unfounded, but reasonable arguments must define the action, which should never be practicable. In a democracy, everyone has the right to have private opinion in the political field, to form freely. This means not only the availability of personal opinion, but it serves as the foundation for active participation in public affairs.

According to the Electoral Code of the Republic of Albania every citizen exercises his right to vote at his polling station, where placed under citizen's location criteria. Voting centers organized in such a way as to facilitate the voting process and ensure the secrecy of the vote. The polls have a tip organization, as defined in the guidelines of the CEC.

Article 330 PCA provides the voter at the polling station the right to vote as the law on electoral system provides or damaged identification documents (identity card or passport, certificate) or using any other form is punishable by six months to a year.

If these illegal actions or non-actions performed more than once to more than one voter, or carried out by the election commissioners shall be punished with imprisonment from one to five years.

When the polling station is threatened or endangered or orderly conduct of the voting, the CEC shall notify the State Police authorities and suspend the voting for

\footnotetext{
${ }^{13}$ Article 330 PCA when the voters at the polling station prevented from exercising his right to vote as the law on electoral system provides or damaged identification documents (identity card or passport, certificate) or using any other form is punishable by six months to a year.

${ }^{14}$ Article 109 / Albanian Electoral Code Order and orderly conduct of the voting at the polling station is not allowed to use a mobile phone by the voter and the voter must not be allowed to vote on keeping a mobile phone in hand. If the voter tries to use the phone camera or any other recording device in the polling station, the same procedure applies as in paragraph 1 of Article 107.
} 
this purpose. The CEC notes the time of notification and suspension of voting in the Book of Meetings the incident that is occurred, the termination of the voting and the time of restarting.

\section{Article $330-a^{15}$ - Abandonment of duty by members of election commissions.}

Often arises between the CEC members who represent different electoral subjects supporting their interests in respect of the relevant law on the progress and democratic development of the elections.

Section 17 of the Electoral Code of the Republic of Albania stipulates the rights and obligations of the members of the CEC.

Exactly when these legal obligations CEC members know very well before you accept function can be abandoned by the latter for many different reasons. Article 330-a PC punish by fine or imprisonment of six months to two years of abandonment of duty without legitimate reasons by members of election commissions, counting members or observers.

Article 330-a has been entered with the changes in Electoral Code of Albania nr.23/2012 law where the legislature wanted to prevent the actions of the members of the CEC as neglect the duty so or refusal to the task of those charged with the administration of the voting process and counting.

If duty drop actions are undertaken by himself or by getting rid of the electoral materials, or have serious consequences for the voting process or have led to the invalidation of the election, shall be punished with imprisonment from two to five years.

\section{Article $331^{16}$ - Violation of the right to vote.}

Democratization entails the removal of state obligations to the behavior of individuals. This leads to uncertainty and confusion about the standards of morality.

The law guarantees the right of voters to vote according to lists and polling relevant under the Electoral Code. This can happened with premeditation or unintentionally,

\footnotetext{
${ }^{15}$ Article 330 / a PC as amended by Law n.23/2012 "Dereliction of Duty by members of election commissions" - Abandonment of duty or refusal to perform the duty of those charged with the administration of the voting process and the counting is punishable with imprisonment from six months to two years. When the above actions are performed by taking away or destroying electoral materials, or have serious consequences for the voting process and led to the invalidation of the election, shall be punished with imprisonment from two to five years.

${ }^{16}$ Article 331 PC amended by Law n.23/2012 "violation of the right of choice" intentional non-inclusion in the voter lists of persons who have the right of choice or by design registration to people who do not have this right, shall be punished with imprisonment from one to five years. The same act committed in cooperation, when there are severel consequences for the interests of the voters or the progress of the electoral process shall be punished by imprisonment of two to five years and a fine from three hundred thousand to seven thousand.
} 
people who meet the constitutional requirements to vote as soon as submitted and denied the right to vote because they have been deleted from the voter list or not appear at all. Namely, when the voter has the right to vote intentionally not included in the list of voters or derecognised deleted illegal is under section 331 PC categorized as criminal offense and is punishable by up to five years. Criminal offense may be committed by unlawful acts or omissions which result in exclusion unfairly voters in electoral lists or registration law against persons who do not have the right to vote.

The law on the conduct of elections determines the criteria of persons entitled to vote and those who do not enjoy this right. And persons who do not have the right to vote or is deprived of this right are: persons to whom this right has been removed by a court, mentally disabled persons when they are declared as such by a court or medical report or citizens who have not attained the age of 18 .

Failure in electoral lists other persons who do not have these aforementioned criteria is image elements of the offense of violation of the right to vote.

But in many cases this offense can be committed in collusion and when there are severe consequences for the interests of the voters or the progress of the electoral process is punishable by two to five years and a fine from three hundred thousand to seven thousand.

These changes were made to the law n.23/2012 while before changing the article in question the offense of violation of right to vote constitute a criminal offense and a much lower sentence which amount to a maximum of one year imprisonment and a fine which was flexible.

\section{Article $332^{17}$ - Abuse of military authority}

Military criminal law has a duty to protect the independence of the state and its territorial integrity, constitutional order, the rights and freedoms of citizens, military order of the Armed Forces, property, authority and military discipline, military offenses and their prevention and to ensure the participation of Albanian citizens in defense of the Republic of Albania.

Duties and important positions in the state having military functions and subordinate other persons as may be soldiers being intertwined personal interests are often a source of abuse and the use of military posts in order to favor one or another electoral subject.

To combat and prevent this phenomenon, the legislature has sanctioned through the coming into force of section 330 PC, which condemns all those subjects who

\footnotetext{
${ }^{17}$ Article $330 \mathrm{PHC} /$ misuse of military authority - abusing military authority by the officer or military framework to influence the voting other military dependents with giving orders, advice or any other propaganda, constitutes criminal contravention and is punishable by a fine or imprisonment up to two years.
} 
perform functions or military officer has a duty under military to influence the voting other military depending constitutes a criminal offense and is punishable by a fine or imprisonment up to two years.

Ways of influencing the salaries in the context of the military who have subordinate entities may be effected by issuing prescriptions, advice or any other propaganda which directly affects the change of the political will of the military voters.

The object of criminal misconduct is to protect the legal relations of the law on democratic electoral system.

\section{Bibliography}

1. Albanian Constitution

2. Albanian Criminal Code

3. Electoral Code of the Republic of Albania

4. PCA amended by Law n.23/2012

5. Ismet Elezi Commentary "The criminal law special part" Tirana 2010

6. OSCE-ODIR Reports http://www.osce.org/ODIHR/Elections/Albania

7. Gjykata e Lartë e Republikës së Shqipërisë http://www.gjykataelarte.gov.al/ 